This is an electronic reprint of the original article. This reprint may differ from the original in pagination and typographic detail.

Author(s): Strömmer, Maiju

Title: $\quad$ Material scaffolding : Supporting the comprehension of migrant cleaners at work

Year: $\quad 2016$

Version:

Please cite the original version:

Strömmer, M. (2016). Material scaffolding : Supporting the comprehension of migrant cleaners at work. European Journal of Applied Linguistics, 4(2), 239-274. https://doi.org/10.1515/eujal-2015-0039

All material supplied via JYX is protected by copyright and other intellectual property rights, and duplication or sale of all or part of any of the repository collections is not permitted, except that material may be duplicated by you for your research use or educational purposes in electronic or print form. You must obtain permission for any other use. Electronic or print copies may not be offered, whether for sale or otherwise to anyone who is not an authorised user. 
Maiju Strömmer*

\title{
Material scaffolding: Supporting the comprehension of migrant cleaners at work
}

DOI 10.1515/eujal-2015-0039

\begin{abstract}
Linguistic diversity is growing in labour markets throughout Europe, including Finland, where cleaning is the most common job for immigrants. This paper explores material scaffolding provided for second language users in tasks involved in cleaning work. The notion of 'scaffolding' refers to temporary and adaptive support, and here the emphasis is especially on 'material scaffolding', that is, material artefacts and body movements employed in mentoring. The theoretical framework of the study is van Lier's (2004) ecological perspective on language learning, and a discourse-ethnographic perspective of nexus analysis (Scollon and Scollon 2004) is adopted to analyse the ethnographic data collected at two work sites. Scaffolding is regarded as a nexus of social practices in which participants, interaction orders and mediational means intersect. The social actions in work encounters are explored to show how space, body movements and material artefacts are employed in work-related communication. The observations on these two work sites suggest that cleaning work can be successfully performed with a beginner's level in the work language as long as guided support is available, and especially if the multiple material mediational means in the immediate surroundings are utilized in scaffolding.
\end{abstract}

Keywords: scaffolding, materiality, nexus analysis, ethnography, language in the workplace, language learning

Zusammenfassung: Sprachliche Vielfältigkeit nimmt auf dem europäischen Arbeitsmarkt zu, inklusive Finnland, wo Reinigungsarbeit die gewöhnlichste Tätigkeit bei Immigranten ist. In diesem Artikel wird die rechtzeitige materielle Unterstützung (Scaffolding) betrachtet, die Zweitsprachensprechern bei Reinigungsaufgaben angeboten wird. Der Begriff des Scaffolding bezieht sich auf eine befristete und adaptive Unterstützung, und hier wird besonders materielles Scaffolding (bzw. die im Mentoring gebrauchten materiellen Artefakte und Körperbewegungen) betont. Der theoretische Bezugsrahmen der Studie ist die ökolo-

*Corresponding author: Maiju Strömmer, University of Jyväskylä - Department of Languages, Department of Languages P.O. Box 35 FIN-40014, University of Jyväskylä, Jyväskylä 40014, Finland, E-mail: maiju.strommer@jyu.fi 
gische Perspektive auf Spracherlernung von van Lier (2004), und eine diskursethnographische Perspektive der Nexus-Analyse (Scollon \& Scollon 2004) wird benutzt, um das an zwei Arbeitsplätzen gesammelte ethnographische Material zu analysieren. Scaffolding wird als ein Netzwerk von sozialen Bräuchen betrachtet, in dem sich die Teilnehmer, Interaktionsordnungen und Mediationsmittel (mediational means) kreuzen. Soziale Begegnungen am Arbeitsplatz werden untersucht, um zu zeigen, wie der Raum, die Körperbewegungen und materiellen Artefakte in berufsbezogener Kommunikation benutzt werden. Die Beobachtungen an diesen zwei Arbeitsplätzen deuten darauf hin, dass man Reinigungsarbeit auch mit elementaren Kenntnissen in der Arbeitssprache gut leisten kann, wenn Unterstützung erhältlich ist, und besonders, wenn die in der unmittelbaren Umgebung erhältlichen materiellen Mediationsmittel im Scaffolding benutzt werden.

Schlüsselwörter: Scaffolding, Materialität, Nexus-Analyse, Ethnografie, Sprache am Arbeitsplatz, Spracherlernung

Resumen: La diversidad de lenguas aumenta en los mercados laborales de toda Europa, inclusive en Finlandia, donde los trabajos de limpieza son los más comunes para los inmigrantes. Este artículo explora cómo son ayudados con andamiaje material (scaffolding) los usuarios de segunda lengua que trabajan en limpieza. El concepto 'scaffolding' se refiere a andamiaje temporal y adaptivo, aquí se enfatiza especialmente 'scaffolding material' (los artefactos materiales y los movimientos corporales utilizados en la mentoría). El marco teórico es la perspectiva ecológica del aprendizaje del idioma de Leo van Lier (2004), y se utiliza una perspectiva discurso-etnográfica del análisis del nexo (Scollon \& Scollon 2004) para analizar los datos etnográficos recabados en dos lugares de trabajo. El andamiaje se ve como un nexo de prácticas sociales en las que los participantes, las órdenes de interacción y los instrumentos mediadores (mediational means) se entrecruzan. Las acciones sociales en encuentros laborales son estudiadas para mostrar de qué manera el espacio, los movimientos corporales y los artefactos materiales son usados en la comunicación laboral. La observación de estos dos lugares de trabajo sugiere que el trabajo de limpieza puede ser realizado con éxito con un nivel de principiante en el conocimiento del idioma siempre y cuando se cuente con una guía, especialmente si se utilizan los instrumentos mediadores materiales del entorno inmediato como andamiaje.

Palabras clave: andamiaje, materialidad, análisis del nexo, etnografía, idioma en el lugar de trabajo, aprendizaje del idioma 
Abstrakti: Kielellinen moninaisuus lisääntyy Euroopan työmarkkinoilla, myös Suomessa, jossa siivous on maahanmuuttajien yleisin työ. Tässä artikkelissa tarkastellaan, miten toisen kielen käyttäjille tarjotaan materiaalista oikea-aikaista tukea siivoustyöhön liittyvissä tehtävissä. 'Oikea-aikainen tuki' (scaffolding) tarkoittaa väliaikaista ja mukautuvaa tukea, ja tässä tutkimuksessa tarkastellaan erityisesti 'materiaalista oikea-aikaista tukea' eli materiaalisten artefaktien ja kehonkielen käyttämistä ohjaamisessa. Tutkimuksen teoreettisena viitekehyksenä on van Lierin (2004) ekologinen näkökulma kielenoppimiseen. Etnografista diskurssintutkimuksen näkökulmaa, neksusanalyysia (Scollon \& Scollon 2004), käytetään kahdessa työkohteessa kerätyn etnografisen aineiston analysoimiseen. Oikea-aikainen tuki nähdään sosiaalisten käytänteiden verkostona, jossa osallistujat, vuorovaikutusjärjestykset ja välittyneisyyden keinot (mediational means) risteävät. Sosiaalista toimintaa työtilanteissa tutkitaan, jotta saadaan selville miten tilaa, kehon liikkeitä ja materiaalisia artefakteja käytetään työhön liittyvässä suullisessa vuorovaikutuksessa. Tutkimukseen osallistuneilla työpaikoilla tehdyt havainnot viittaavat siihen, että siivoustyössä pystyy suoriutumaan hyvin myös alkeistason kielitaidolla, jos tukea on saatavilla. Parhaiten ymmärtäminen varmistuu, jos ympäristössä saatavilla olevia materiaalisia välittäjiä käytetään hyväksi oikea-aikaisessa tuessa.

Avainsanat: scaffolding, materiaalisuus, neksusanalyysi, etnografia, kieli työpaikalla, kielen oppiminen

\section{Introduction}

Cultural and linguistic diversity is growing in the labour markets throughout Europe, and this is posing a challenge to organizations' language practices and institutional policies (see Duchêne et al. 2013). Finland has long been a comparatively monolingual country and therefore Finnish workers are often not used to communicating with co-workers who speak Finnish as a second language. As in many other European countries, cleaning is the most common job for immigrants in Finland because of the flexible language requirements and demand for labour in the area (OSF 2013; Trux 2002; Ozyegin and HondagneuSotelo 2008). As a result, work communities in the cleaning sector are often linguistically diverse, which makes it difficult to find appropriate language practices for orientation, supervision and teamwork. The aim of this paper is to locate good practices that could guide linguistically diverse work communities to provide scaffolding and achieve mutual understanding on work-related issues. 
In this article, an ethnographic discourse analytic perspective of nexus analysis (Scollon and Scollon 2004; see also Pietikäinen et. al 2011; Hult 2014) is taken to analyse how cleaning supervisors and co-workers support migrant cleaners and help them to understand and perform their work tasks. The notion of scaffolding refers to temporary and adaptive support, and here the emphasis is especially on material scaffolding, that is, material artefacts and body movements employed in mentoring. Specifically, the research addresses the question, How do colleagues provide material scaffolding for second language users in tasks involved in cleaning work? This question will be answered by referring to ethnographic and interactional data collected at two work sites.

Many studies (e.g. Suni 2010, Virtanen 2013, author 2013) have found that the support received from work communities is essential for language learning at work, but only a few of these (e.g. Sandwall 2010, Virtanen 2015) have analysed interaction and social actions in actual work tasks. In sociocognitive and ecological perspectives in particular, material, embodied, and situated aspects of language learning are foregrounded in addition to the social nature of learning (van Lier 2004, Kramsch and Steffensen 2008, Dufva et al. 2011). In research on language use at work, e.g. de Saint-Georges (2004), Filliettaz (2013), and Izadi (2015) have also taken material and spatial elements into account. However, these angles - language learning and materiality at work - have not hitherto been combined in empirical research. This paper aims to provide insights into language learning and materiality by exploring material scaffolding in work-related tasks.

\section{Material scaffolding in the work environment}

This study draws on van Lier's (2004) ecological approach, which is based on Vygotskian socio-cultural perspectives on learning and the Bakhtinian dialogical philosophy of language. Following this approach, language should be explored in actual situations and contexts because it is realised only in use (van Lier 2000, 2004). Language ecology is a holistic approach that analyses also the semiotics, artefacts and embodiment used in linguistic action because they are significant aspects of communication (van Lier 2004; Barab and Roth 2006). The present study attends to these aspects by focusing on the materiality and scaffolding in work-related social actions.

From the ecological perspective, language learning requires perception and active engagement on the part of the individual, but the environment has a crucial role, too: it is a semiotic budget, which provides opportunities for meaningful actions in different situations (van Lier 2000: 252). The relations between 
individuals and their social and physical surroundings are referred to as affordances. Originally, the concept of affordance comes from the ecological psychology of Gibson (1979: 127), who defined it as a reciprocal relationship between an animal and its environment: it is a resource that the environment offers "for good or ill”. According to van Lier (2000: 252-253; 2004: 62), the linguistic resources in the environment become learning opportunities only when a language user perceives them and chooses to use them. Resources are turned into affordances when they are used for meaningful action. In addition to the resources attached to the physical surroundings such as a workplace, also other people in the surroundings, in this study mostly co-workers, can offer affordances for social action.

The present study explores work-related encounters in which second language users need guided support from their co-workers in order to interpret the linguistic resources. Wood, Bruner and Ross (1976: 98) established the concept of scaffolding to refer to the problem-solving situations where learners manage with adaptive help. Scaffolding is connected to the Vygotskian socio-cultural theory of learning and particularly to the notion of the Zone of Proximal Development (Vygotsky 1978: 85). This notion refers to a metaphorical area of potential development where learners can manage with the help of others but not on their own. Traditionally, scaffolding has been defined quite narrowly as the mentoring given to children by adults or more advanced language users, usually in dyadic interactions in L1. However, more recent research has shown that the concept is also useful for second language learning, and peers as well as experts can provide scaffolding (see Hakamäki 2005: 54). Some studies have focused primarily on the party that provides support, but e.g. Nassaji and Swain (2000: 36) and Suni (2008: 122) regard scaffolding as a reciprocal activity in which meanings are built together on the basis of the learner's needs. This study draws on this reciprocal and dialogical view of scaffolding.

Research on second language learning has focused primarily on verbal scaffolding in educational settings, such as scaffolded assistance in language teaching (Nassaji and Swain 2000; Hakamäki 2005; Smit, van Eerde and Bakker 2013), peer scaffolding in collaborative learning (Nguyen 2013; Hanjani and Li 2014), and scaffolding strategies for technology-mediated language learning (Huang and Huang 2015; Jung and Suzuki 2015; Lehtonen 2013). Scaffolding strategies in workrelated settings have received much less attention. Orlikowski $(2005 ; 2007)$ has explored material scaffolding afforded by the infrastructure, technologies and spaces in business organisations and Filliettaz (2013) multimodal and interactional support in car mechanics' work tasks. Furthermore, Carter et al. (2006) investigated how gestures enhance scaffolding in small group situations in science class. However, these studies do not deal with language learning. This study examines the scaffolding provided for second language speakers of Finnish in two 
workplaces. The emphasis is on the material nature of scaffolding, henceforth called material scaffolding. This term is used here to describe the use of material artefacts and embodied actions in physical places in scaffolding situations.

Embodied actions have been mostly studied in the field of multimodal interaction analysis, which focuses on embodied interaction in the material world, such as the use of gaze, gestures, body movement and position in meaningmaking (e.g. Goodwin 2003; Lerner 2002; Streeck et al. 2011). Furthermore, there is a growing interest in studying the use of material artefacts in different institutional and technological settings, within workplace studies in particular (Hindmarsh and Heath 2000; Koschmann et al. 2006; Heath and Luff 2013). Hindmarsh and Heath (2000: 527) stress the need to understand how the objects in working environments feature within the course of work-related activities. Goodwin (2003; 2013) takes even a more holistic view by emphasizing the significance of social, cultural and physical aspects of surroundings when analysing situated social actions carried out through semiotic resources.

This article takes also spatiality into consideration by analysing the affordances and restrictions for interaction posed by the places (see Scollon and Scollon 2003). Actions are always spatially situated, and different spaces offer different material arrangements that might be tied to specific activities - therefore, spaces and places constrain and shape actions (Crabtree 2000). This study shows how the particular spaces in the workplace facilitate or restrict interaction in second language.

\section{Data and methodology}

\subsection{Nexus analysis}

Nexus analysis (Scollon and Scollon 2004) is an ethnographic discourse analytical approach that combines methodological tools from the traditions of linguistic ethnography, discourse analysis and interactional sociolinguistics. Researchers have applied nexus analysis in different fields to study social actions connected to e.g. minority languages (Pietikäinen 2010, Lane 2010), disabilities (Al Zidjaly 2006), language policy and planning (Hult 2010, Compton 2013), and tourism in the new economy (Dlaske 2015). Simon-Maeda (2009), Källkvist (2013), Tapio (2013), and Virtanen (2015) have conducted nexus analytical research on language learning, and the present paper follows in this field of study.

Following Scollon and Scollon's practical field guide (2004: 152-178), ethnographic research begins with engaging the field and locating the meaningful social actions for the focus of the study. Based on my observations, field notes, 
interviews, and recordings, I located the most common interaction situations typical of cleaning work at two work sites. In the first workplace, the most common work-related interaction situation was supervising: the cleaning supervisors gave instructions to the cleaner every week. In the second workplace, the cleaning team consisted of five cleaners, who often discussed their work shifts and tasks together during their coffee and lunch breaks. In the analysis I will therefore focus on those situations.

In nexus analysis, the three main elements circulating through the focal actions are 1) discourses in place, 2) historical bodies and 3) the interaction order. Scollon and Scollon (2004: 14) emphasize that actions always take place in a material place, where different cycles of discourses intersect. The present study attends to this dimension by analysing spoken discourse along with those artefacts and the characteristics of the physical place that are meaningful for the social action. The historical body, in turn, refers to the embodied practices and life experiences of the individual social actors. Here, this dimension is analysed to explain why the participants carry out actions the way they do; different people act differently in the same situations as a result of their personal experiences (Scollon and Scollon 2004: 13). Especially the knowledge I gained from interviews and informal conversations with the participants offered me insights into their historical bodies. Finally, the concept of an 'interaction order', which comes from the work of Goffman (1983), covers the different social arrangements by which people come together in social groups, whether for instance a platform event, a meeting, a conversation, or a queue (Scollon and Scollon 2004: 19). From the nexus analytic perspective, social actors and discourses come together in the interaction order to enable some social action.

To analyse how material scaffolding is co-constructed through different actions at work encounters, I apply three categories of actions developed by Sigrid Norris within one of the applications of nexus analysis, referred to as mediated discourse analysis (Scollon 2001; Norris and Jones 2005). Lower-level actions are the smallest interactional meaning units, higher-level actions are composed of a chain of lower-level actions and have an opening and a closing, and frozen actions are entailed in material artefacts (Norris 2004: 102). Higherlevel actions are constructed through numerous simultaneous lower-level actions in different communicative modes (Norris 2004: 102).

Mediated discourse analysis is inextricably tied together with nexus analysis, and they both take the social action as an analytical unit. All human actions are mediated, as they are performed by a social actor with or through mediational means (Scollon 2001: 3; Scollon and Scollon 2004: 12). Mediational means (or cultural tools, see Vygosky 1978; Wertsch 1991) include both material artefacts such as a computer or a calendar, and psychological tools such as language and 
other symbol systems, through which mediated actions are carried out (Norris and Jones 2005b: 49). Spoken language is only one of the many available mediational means with which people take actions (Jones and Norris 2005: 4). Hence anything and everything that is significant in the situation - such as space, physical layout, written or multimodal texts, actions and body positions - is taken into account (Norris 2004). Therefore, it is necessity not only to gather data in many modes (audio, visual, textual), but also to do that with different people at different stages to cover different points of view of subjectivities (generalizations, experiences, observations and comparisons) (Norris and Jones 2005c: 202).

In this article the data examples in foci are audio- or video-recordings accompanied by observations made during the recording sessions. I wrote field notes as the situations progressed and worked them on afterwards. When analysing audio recorded actions, the emphasis is on those mediational means that are discovered to be meaningful for the situated social actions on the basis of ethnographic observations and that can be analysed reliably from the different kinds of data that are available. Audio-recordings carry a lot of information about movements and artefacts, too (e.g. the sound of footsteps, the clicks of a mouse, the creak of a door).

I will present so-called ethnographic vignettes (Erickson 1986: 163, Pietikäinen et al. 2008, Hult 2014) based on the field notes before presenting the transcripts in order to give background knowledge to the interaction situations. These vignettes elaborate upon the field notes and take a narrative form.

\subsection{Key participants and data collection}

The ethnographic data ${ }^{1}$ of this study were collected at two workplaces in Finland. In these workplaces, I followed the social actions of three key participants: Kifibin, Omar and Mae Noi. Kifibin moved to Finland to do a Master's Degree, and Mae Noi and Omar both moved here to marry a Finnish partner. Originally, Kifibin is from Uganda, Omar from Gambia, and Mae Noi from Thailand.

I got to know Kifibin in the spring semester of 2012 when he took part in a Finnish course I taught, hence we had initially a student-teacher relationship. In the autumn of 2012 I contacted him and asked him if he would like to take part in my study, and he agreed. My first encounter with Omar and Mae Noi was in May

1 The data collection was implemented as part of the project Finnish as a Work Language: A Sociocognitive Perspective to Work-related Language Skills of Immigrants (University of Jyväskylä, funded by The Emil Aaltonen Foundation). The names of the participants are changed and some details have been removed to ensure the anonymity of the participants and companies. 
2013 on their employer's premises when I met the migrant cleaners working there to introduce my study to them and recruit them to take part. Five cleaners came and they all wanted to be interviewed. After the interview, Mae Noi and Omar were most willing to let me follow and record their working days, as well.

I conducted the fieldwork at Kifibin's workplace from January to March 2013. He works for a large private cleaning company, and at that time he was cleaning in a big event centre. To gain insights into another workplace, I carried out fieldwork from February to August 2014 with Mae Noi's and Omar's cleaning team. They work in a large specialist organization that directly employs its own cleaning personnel. I was an outsider in these workplaces as I was not officially part of those work communities. To get to know the setting and to gain understanding for my research project, I spent a total of 15 days following the key participants and their work and participating in discussions with members of their work communities. During the fieldwork I wrote field notes on work routines as well as on interactions and practices within the work community. I also recorded interaction situations during the workdays and interviewed the cleaners and their supervisors and managers about language practices in cleaning work (see Table 1). To allow shadowing and moving around, I mostly used a light audio-recording device because cleaners move quickly and change locations constantly. I wrote field notes during and after the recording sessions and transcribed the data as soon as possible to insert contextual knowledge into the transcriptions.

Table 1: Overview of the data.

\begin{tabular}{|c|c|c|}
\hline & Kifibin's workplace & Omar's and Mae Noi's workplace \\
\hline Observation & $\begin{array}{l}9 \text { days during two months in } 2013 \text { : } \\
\text { 29.1., 30.1., 21.2., 22.2., 25.2., 12.3., } \\
\text { 13.3., 25.3., 26.3. }\end{array}$ & $\begin{array}{l}7 \text { days during } 6 \text { months in } 2014 \text { : } \\
\text { 5.2., 12.2., 19.2., 25.2., 29.4., 5.6., } \\
\text { 30.7. }\end{array}$ \\
\hline $\begin{array}{l}\text { Audio } \\
\text { recordings }\end{array}$ & 18 files, 157 minutes in total & 10 files, 225 minutes in total \\
\hline $\begin{array}{l}\text { Video } \\
\text { recordings }\end{array}$ & - & 2 files, 41 minutes in total \\
\hline Interviews & $\begin{array}{l}7 \text { semi-structured interviews: } \\
\text { Kifibin: } 10.12 .2012,26.3 .2013, \\
\text { 24.4.2014 } \\
\text { Mira (cleaning manager): } 25.2 .2013 \\
\text { Katri (cleaning supervisor): } 30.1 .2013 \text {, } \\
\text { 13.3.2013 } \\
\text { Kaija (restaurant manager): } 22.2 .2013\end{array}$ & $\begin{array}{l}6 \text { semi-structured interviews: } \\
\text { Omar: } 23.5 .2013,5.6 .2014 \\
\text { Mae Noi: } 29.5 .2013,30.7 .2014 \\
\text { Maarit \& Sirpa (Finnish cleaners in } \\
\text { the cleaning team): } 27.8 .2014 \\
\text { Mari (cleaning supervisor): } 29.4 .2014\end{array}$ \\
\hline Photographs & $\begin{array}{l}\text { Over } 200 \text { photographs taken by the } \\
\text { researcher and } 10 \text { taken by Kifibin }\end{array}$ & $\begin{array}{l}\text { About } 100 \text { photographs taken by the } \\
\text { researcher }\end{array}$ \\
\hline
\end{tabular}


During the fieldwork I became established as a regular and familiar visitor in the cleaning teams. I am also present in the data: I was there recording the interactions, conducting the interviews and writing the notes, and this affects the nature of the data. An ethnographer's presence in the field always somehow affects the practices of the participants, and I have therefore not tried to detach my presence from the data and results.

\section{Findings}

\subsection{Kifibin's workplace: Spatial elements of giving instructions}

In this section, the analysis focuses on the spatial elements in scaffolding provided to Kifibin by his Finnish supervisors, Mira and Katri. Kifibin's cleaning area is a large and complex centre where a big sporting event is organized every week. It consists of multiple buildings, areas and rooms. All the halls, cafeterias and restaurants are closed when he is cleaning. From the ecological perspective, Kifibin's cleaning area is big and includes many different types of areas, but his niche is tight as far as social communication is concerned: he is not regarded as a full member of the work community and cannot attend the informal events of the client organization (see more Strömmer 2016). Moreover, as Kifibin is the only cleaner in the workplace, he does not meet his workmates from the cleaning company every day. However, because there are often extra cleaning tasks and changes in the cleaning routine, Kifibin regularly gets instructions from his supervisors. The supervisors visit the workplace or give instructions over the phone or via text messages.

Figure 1 illustrates the three dimensions of the nexus. The chosen situations are one-to-one between Kifibin and either his manager, Mira, or his supervisor, Katri. Mira is a Finnish woman who has worked as a cleaning manager for six years and is used to giving instructions to migrant employees, also in English. She lived in England for six months as an exchange student ten years ago and gained there the confidence to speak "broken" English. Katri is a young Finnish woman who has worked as a cleaning supervisor for a year. She is also used to working with migrant cleaners because one third of her subordinates are migrants. Kifibin has worked for the company observed in this study for four years, part-time while he was studying and, since graduating, full-time. Mira and Katri have supervised him for a year. Thus they already all know each other quite well. Previously, Mira and Katri had given Kifibin instructions in English as it was a strong common resource between them, but during the fieldwork they spoke mostly Finnish. Kifibin's mother tongue is Luganda and the language of his schooling was English. His Finnish language skills are at the intermediate level (B1 in the CEFR). 


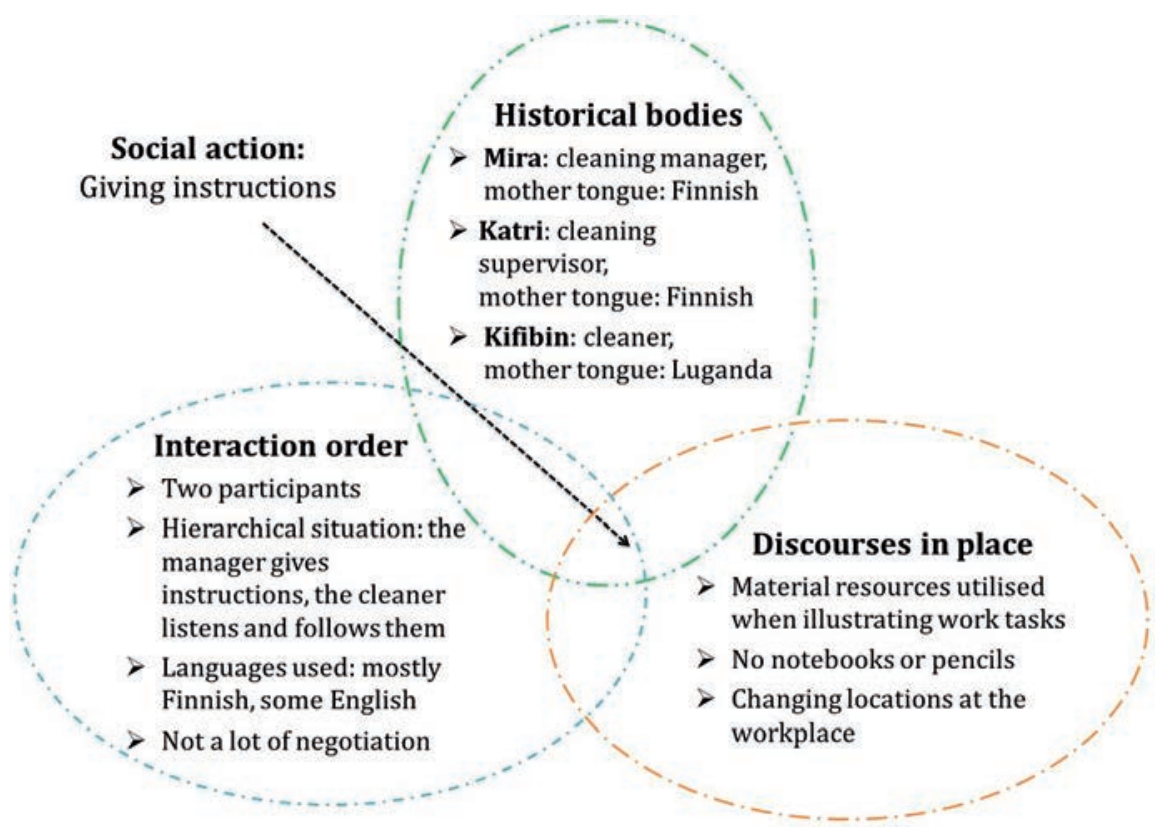

Figure 1: Nexus of giving instructions (Application from Scollon \& Scollon 2004: 20).

The interaction order of the instructing situations is hierarchical: the institutional roles of manager and subordinate are clearly present. The situations are goaloriented: the aim is to communicate the instructions so that the cleaner can perform the tasks accordingly. As the Finnish language is a second language for Kifibin, the supervisors use different ways to make the instructions more concrete. In the interview, Mira said that the biggest problem with the inadequate Finnish language skills of the cleaners is that it is sometimes difficult for them to follow the instructions, and that although the tasks can be shown, it is a challenge for them to remember all the tasks. Against this background it is worth noting that the supervisors do not give the instructions in writing and the cleaner does not take notes during the supervisors' visit, although many detailed instructions are given at once. However, the supervisors provide scaffolding by actively employing material mediational means such as a calendar, cleaning equipment and the objects to be cleaned.

Next, actual social actions are analysed in more detail to show how Katri and Mira provide Kifibin with material scaffolding. The most meaningful embodied actions are written in the transcription based on the audio-files and field notes (see Appendix 1). The actions continue and complete the oral instructions, which is evident as the silences are often filled in with the actions. Before the excerpts, 
ethnographic vignettes developed from the field notes are presented to provide a background to the work situations.

Last Friday, when we were walking from Kifibin's workplace to the bus stop, Mira called Kifibin. After the phone call Kifibin told me that Mira would come on Monday to instruct him in an extra task that the client had ordered. Kifibin was surprised that the phone call did not cause him any particular problems - speaking in Finnish on the phone had been tough for him before, since it offers no other modes than voice. The following Monday I followed Kifibin's morning routines at work. At 10 am we entered the main lobby, where Mira was already waiting for us. She greeted us and told us that she had tried to find us everywhere. In addition, she said, "Let's speak Finnish!" Kifibin replied, "A bit." and Mira commented, "A lot!" We started to climb the stairs to a tower where the extra task was to be carried out. Climbing the stairs took over five minutes. When we were finally in the tower, Mira demonstrated and explained the task: Kifibin was supposed to lift the floor tiles and vacuum the floor under them.

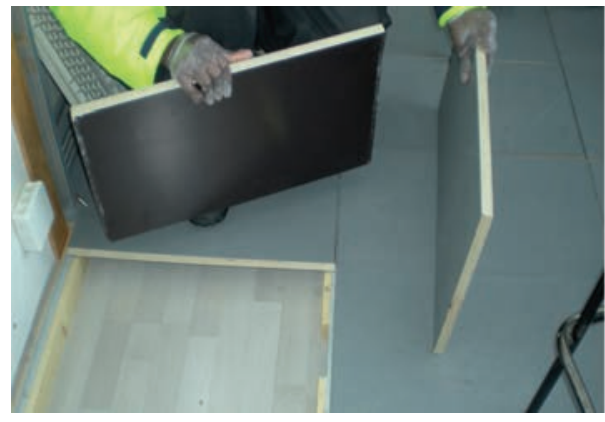

Figure 2: Floor tiles.

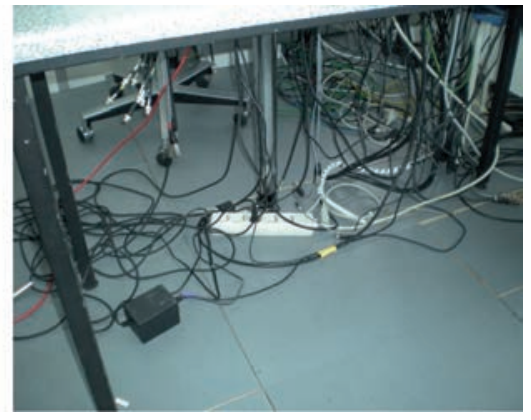

Figure 3: Cords under the table.

Excerpt 1: Demonstrating a particular cleaning task in a tower.

Participants: Mira (cleaning manager, Finnish, female), Kifibin (cleaner, Ugandan, male), Maiju (researcher, Finnish, female).

Data: audio-recording and notes based on ethnographic observations.

\begin{tabular}{lll}
\hline $\mathbf{0 1}$ & Mira & krh krh krh (1.4) tämä tila \\
\hline & \multicolumn{2}{c}{ krh-krh-krhh (1.4) this place } \\
\hline $\mathbf{0 2}$ & Kifibin & mhm \\
\hline $\mathbf{0 3}$ & Mira & täältä alta (.) kun nämä nousee (1.3) niin pitäis imuroida \\
\hline \multirow{2}{*04}{} & Kifibin & ookown here (.) as these can be raised ((lifts a floor tile)) (1.3) you should vacuum \\
\hline \multirow{2}{*05}{} & Mira & okay \\
\hline & nää kaikki nousee \\
\hline
\end{tabular}


Excerpt 1: (continued)

\begin{tabular}{|c|c|c|}
\hline 06 & Mira & $\begin{array}{l}\text { ja missä on toi pöydänjalka (.) niin otat sitten imurilla vaan koska noita ei saa } \\
\text { nostettuu }\end{array}$ \\
\hline & & $\begin{array}{l}\text { and where that table leg is (.) just take it with the hoover because you can't lift } \\
\text { those ((points at table legs and the floor tiles under them)) }\end{array}$ \\
\hline \multirow[t]{2}{*}{07} & Kifibin & ookoo \\
\hline & & okay \\
\hline \multirow[t]{2}{*}{08} & Mira & $\begin{array}{l}\text { paljon johtoja (2.3) elikkä täältä niin pitkälle kun pääset tuolta nostaa näitä nii } \\
\text { (.) nää pitäää imuroida täältä }\end{array}$ \\
\hline & & $\begin{array}{l}\text { lots of cords (2.3) so from here for as far as you can lift these (.) these need to be } \\
\text { vacuumed here }\end{array}$ \\
\hline 09 & Kifibin & $\mathrm{mhm}$ \\
\hline \multirow[t]{2}{*}{10} & Mira & kuten huomaat tulee pölyä (1.6) otat yhden pois ja (.) sitte nostat seuraavajja \\
\hline & & $\begin{array}{l}\text { as you see there's dust coming (1.6) (the creak of a floor tile)) just take one } \\
\text { away and (.) then you raise the next one and }\end{array}$ \\
\hline \multirow[t]{2}{*}{11} & Kifibin & ookoo \\
\hline & & okay \\
\hline \multirow[t]{2}{*}{12} & Mira & nää kaikki imuroit mistä pääset (1.8) näin \\
\hline & & vacuum all these where you can ((a creak)) (1.8) like this \\
\hline
\end{tabular}

This excerpt shows the opening of a higher-level action - giving instructions which is composed of many multimodal lower-level actions (Norris 2004). The supervisor utilises the materiality of the particular task in many ways: she demonstrates how to lift up the floor tiles (lines 3 and 5) and points to the significant artefacts (cords and a table leg, line 6). Her embodied actions are parallel to the oral instructions, which is typical; people tend to gesture while speaking and their gestures and speech usually convey the same meaning (Gullberg 2006: 106). As we are in the room where the task needs to be performed (see Figures 2 and 3), the surroundings offer many relevant affordances for the interaction situation (van Lier 2000: 252). Employing the mediational means of the material place enables quite deictic language use - there is no need to strive for accurate linguistic explanations when everything can be shown in practice (see also Paananen 2015: 89). Instead, most of the expressions above make sense only as embedded in their context and connected with the body movements, for instance "this place" (not naming the place), "down here" (showing the direction of attention), and "as these can be raised" (not naming the floor tiles in Finnish). Although the linguistic explanation is vague, Kifibin signals that he is following the instructions: he does not ask anything or 
hesitate. Instead, his turns are brief dialogue particles such as mhm and okay. By these lower-level actions Kifibin expresses that he is listening to Mira and watching what she is doing.

In the next two examples, it is not so easy to understand the tasks. Both excerpts are from the same situation just a minute after the previous one: we are now walking downstairs and Mira is continuing to give Kifibin instructions. On the staircase, many embodied elements of communication, such as eye contact, gestures, and body positions, cannot be fully employed. The supervisor does not employ any material artefacts to provide scaffolding, either, but the scaffolding is mostly verbal. Therefore the physical layout makes the communication more difficult; the architecture of a space sometimes restricts interaction (Tapio 2013: 61). During the walk downstairs we stop twice: first in Excerpt 2 and then again in Excerpt 3. These stops can be considered key moments as Kifibin seems to have a hard time understanding the instructions at these points and thus scaffolding is needed.

Excerpt 2: Giving instructions while walking downstairs: case 1, 'tuulikaappi' (wind closet).

\begin{tabular}{|c|c|c|}
\hline 01 & Mira & sitten samalla tota niin toi [Matti] pyysi kun siellä \\
\hline & & at the same time uh well [Matti] asked that there \\
\hline 02 & & ((They all stop walking.)) \\
\hline \multirow[t]{2}{*}{03} & Mira & on siellä toimistot mitkä sää siivoot kolme kertaa viikossa \\
\hline & & there are the offices that you clean three times a week \\
\hline \multirow[t]{2}{*}{04} & Kifibin & mhm (.) mutta \\
\hline & & $m h m($.$) but$ \\
\hline \multirow[t]{2}{*}{05} & Mira & niin siellä kun on se pieni tuulikaappi \\
\hline & & so there is that small wind closet [entrance room] \\
\hline \multirow[t]{2}{*}{06} & Kifibin & tuulikaappi? \\
\hline & & wind closet? \\
\hline \multirow[t]{2}{*}{07} & Mira & tuulikaappi \\
\hline & & wind closet \\
\hline \multirow[t]{2}{*}{08} & Kifibin & missä \\
\hline & & where ((slowly)) \\
\hline \multirow[t]{2}{*}{09} & Mira & mistä tullaan sisälle pihalta (.) sinne toimistoon \\
\hline & & where you come in from outside (.) into the office \\
\hline 10 & Kifibin & $\mathrm{mhm}$ \\
\hline \multirow[t]{2}{*}{11} & Maiju & eteinen \\
\hline & & an entrance hall \\
\hline
\end{tabular}


Excerpt 2: (continued)

\begin{tabular}{lll}
\hline 12 & Mira & [eteinen (.) se \\
\hline & & [an entrance hall (.) that \\
\hline 13 & Kifibin & [mhm mhm mhm \\
\hline 14 & Mira & niin sieltä nostaa sen maton aina pois ja imuroi sieltä \\
\hline & & so there lift up and take away the doormat and hoover there \\
\hline 15 & Kifibin & mhm mhm mhm mhm \\
\hline 16 & & ((They start to walk.)) \\
\hline
\end{tabular}

In this example, the movement stops in line 2 when Mira is talking about a specific place: a small entrance room into the offices (lines 3 and 5). Mira tries to support understanding in many ways, and stopping moving may be a way to calm the situation and offer better conditions for concentrating on the instructions and providing embodied scaffolding. Kifibin had mentioned that Finnish-mediated phone calls were difficult for him to understand because visual and spatial modes and material artefacts cannot be used during a traditional phone call. Walking down the stairs imposes similar constraints on communication, because eye contact cannot be maintained safely.

In line 6, Kifibin repeats the place with a rising intonation. In Lilja's study (2010), partial repetitions by second language speakers in everyday Finnish interactions were treated as indications of not understanding the meaning of the repeated element. Here the source of the problem, which is repeated, is the infrequently used compound word tuulikaappi. It means literally 'a wind closet', which is a small entrance room between the front door and another door, the purpose of which is to prevent cold air coming inside during the winter months. Even when Mira has repeated the word tuulikaappi (line 7), Kifibin seems to be confused as he asks missä ('where') really slowly and thoughtfully (line 8). After that, the supervisor tries to explain the place in more detail (in line 9) and repeats the synonym offered by the researcher (lines 11 and 12). At this point, Kifibin is signalling understanding, because he repeats three times "mhm" in line 13, after which Mira finally gives the instructions for the task that has to be carried out (line 14). Then she walks on and gives more instructions. 
Excerpt 3: Giving instructions while walking downstairs: case 2, 'sosiaalitila' (social space).

\begin{tabular}{|c|c|c|}
\hline \multirow[t]{2}{*}{01} & Mira & sitten meidän pitäis käydä tuolla [ravintolassa] \\
\hline & & then we should go to the [restaurant] \\
\hline \multirow[t]{2}{*}{02} & Kifibin & ookoo \\
\hline & & okay \\
\hline \multirow[t]{2}{*}{03} & Mira & $\begin{array}{l}\text { kanssa kattomassa yksi (1.3) että tarvisko (.) siä pieni sisäänkäynti mistä } \\
\text { mennään aamulla sisälle }\end{array}$ \\
\hline & & $\begin{array}{l}\text { to see too (1.3) if there is a need to (.) the small entrance where you go in in the } \\
\text { morning }\end{array}$ \\
\hline 04 & Kifibin & $\mathrm{mhm}$ \\
\hline \multirow[t]{2}{*}{05} & Mira & ja sitten se naisten sosiaalitila henkilökunnalle \\
\hline & & and then the women's staff-room \\
\hline \multirow[t]{2}{*}{06} & Kifibin & ookoo \\
\hline & & okay \\
\hline \multirow[t]{2}{*}{07} & Mira & eikö ne oo kerran viikossa vaan niitten siivous (.) muistanko oikein (2.1) \\
\hline & & don't they get cleaned just once a week (.) do I remember correctly (2.1) \\
\hline 08 & & ((Everyone stops walking.)) \\
\hline \multirow[t]{2}{*}{09} & Mira & tuulikaappi ja se naisten sosiaalitila \\
\hline & & the wind closet [entrance room] and the women's staff-room \\
\hline \multirow[t]{2}{*}{10} & Kifibin & naisten \\
\hline & & the ladies' \\
\hline \multirow[t]{2}{*}{11} & Mira & henkilökunnan (.) se pieni (.) niin eikö ne ollu kerran viikossa vaan siivous \\
\hline & & the staff's (.) the small one (.) so isn't it only once a week their cleaning \\
\hline \multirow[t]{2}{*}{12} & Kifibin & kerran viikossa \\
\hline & & once a week \\
\hline \multirow[t]{2}{*}{13} & Mira & joo (.) niin mää muistelin \\
\hline & & yeah (.) that's what I thought \\
\hline \multirow[t]{2}{*}{14} & Kifibin & tai ainakin torstaina \\
\hline & & or at least on Thursday \\
\hline 15 & & ((Everyone starts to walk.)) \\
\hline
\end{tabular}

As in Excerpt 2, so too here in Excerpt 3, the source of the problem seems to be a physical place, namely a women's staff room. The supervisor again uses a strange word, 'sosiaalitila' (literally 'social space'), in line 5. At first Kifibin only listens to what Mira says and replies saying "mhm" and "okay". In line 7, Mira asks a question that Kifibin does not answer immediately but there is a notice- 
able silence of 2 seconds, which might implicate a problem in the flow of interaction (see Jefferson 1989: 171). After this silence everyone stops walking and Mira elaborates on her question by mentioning the places tuulikaappi and sosiaalitila again (line 9). Kifibin partially repeats Mira's turn in line 10 and Mira gives more information about the place she is talking about ("the staff's" and "the small one"). After that, she repeats her question in line 11 and now Kifibin replies to the question, in lines 12 and 14. Kifibin's reply confirms that mutual understanding has been reached, and they start walking downstairs again in line 15.

After this we went to the restaurant, where the supervisor pointed out the place she had been talking about in line 5 ("the staff's room") in order to show where exactly the extra cleaning task should be performed. However, she did not point out to Kifibin the small entrance room (wind closet) into the offices nor the exact point to vacuum there (under the doormat), which was the source of the problem in Excerpt 2.

Two weeks later another supervisor, Katri, is visiting Kifibin's workplace to give further instructions. She again asks Kifibin to vacuum under the doormat in the offices' small entrance room, and it becomes evident that he has not understood the instructions the first time.

Two weeks after Mira's visit, Kifibin is cleaning in an empty restaurant kitchen when Katri suddenly enters the room. She greets us and asks Kifibin how it is going. Kifibin tells her that there was a lot of rubbish in a restaurant he cleaned earlier in the morning. Katri consoles him by reminding him that there are not many days left in this workplace. She starts to give instructions for the last remaining days in this client's premises, because the cleaning contract with them will end soon - another cleaning company won the tendering. At the end, she asks about the same task that Mira asked Kifibin to do when she visited the workplace.

Excerpt 4: Repeated instruction.

Participants: Katri (cleaning supervisor, Finnish, female), Kifibin (cleaner, Ugandan, male), Maiju (researcher, Finnish, female).

Data: audio-recording and notes based on ethnographic observations.

\begin{tabular}{lll}
\hline 01 & Katri & ja voitko kattoo tosta mitkä toimistot teet kolme kertaa viikossa \\
\hline & & and could you check those offices where you clean three times a week \\
\hline $\mathbf{0 2}$ & Kifibin & yhy \\
\hline $\mathbf{0 3}$ & Katri & niin sieltä se toinen sisäänkäynti mistä ne miehet tulevat sisään \\
\hline & & there is the other entrance where the men come in \\
\hline $\mathbf{0 4}$ & Kifibin & mhm \\
\hline
\end{tabular}


Excerpt 4: (continued)

\begin{tabular}{|c|c|c|}
\hline \multirow[t]{2}{*}{05} & Katri & niin sen pienen tuulikaapin maton alusen lähteekö se puhtaaks vai ei \\
\hline & & $\begin{array}{l}\text { under the doormat in the small wind closet [entrance room] (.) can you get it } \\
\text { clean or not }\end{array}$ \\
\hline \multirow[t]{2}{*}{06} & Kifibin & ookoo ((hiljaa)) \\
\hline & & okay ((quietly)) \\
\hline \multirow[t]{2}{*}{07} & Katri & mä en tiedä lähteekö se mutta ilmota mulle jos ei se lähde \\
\hline & & I don't know if it is possible to get it clean or not but let me know if it isn't \\
\hline \multirow[t]{2}{*}{08} & Kifibin & ookoo \\
\hline & & okay \\
\hline \multirow[t]{2}{*}{09} & Katri & mhm (.) ymmärsitkö kaiken \\
\hline & & mhm (.) did you understand everything \\
\hline \multirow[t]{2}{*}{10} & Kifibin & [joo \\
\hline & & lyeah \\
\hline \multirow[t]{2}{*}{11} & Katri & [mitä puhun vai puhuinko liian nopeesti \\
\hline & & [that I say or do I speak too fast \\
\hline 12 & & ((Kifibin laughs.)) \\
\hline \multirow[t]{2}{*}{13} & Katri & $\begin{array}{l}\text { ainakaan (.) ((katsoo tutkijaa)) [Kifibin] on aina joo joo ja sitten vaan miettii } \\
\text { että tulee tota kaikki selväks (.) }\end{array}$ \\
\hline & & $\begin{array}{l}\text { at least ((looks at the researcher)) [Kifibin] is always like yes yes and then I just } \\
\text { wonder if everything is really clear }\end{array}$ \\
\hline \multirow[t]{2}{*}{14} & Katri & ((katsoo Kifibiniä)) mutta hyvin sä jo osaat \\
\hline & & ((looks at Kifibin)) but you can already speak well \\
\hline
\end{tabular}

This excerpt is taken from the middle of the higher-level action: Katri's visit at Kifibin's workplace to give him instructions. Two points are particularly worth our attention: firstly, that Kifibin did not follow the instructions Mira gave him two weeks ago about vacuuming under the doormat (line 5), and secondly, that Katri is unsure whether Kifibin understands all the instructions she gave (line 13). After Katri's visit, I discussed the vacuuming task with Kifibin and it became evident that he had not remembered it. This shows how effective it is to show the places where a task needs to be performed. At the end of the excerpt above, Katri asks (line 9) if Kifibin has understood everything and Kifibin says yes (line 10). After that the supervisor explains to the researcher that it is sometimes hard to know if Kifibin has understood, since he always says that he has (line 13).

Kifibin's reasons for not always showing when he has difficulties understanding the instructions remain unclear. The interviews and observations indicate that 
Kifibin finds it complex and challenging to manage in a second language at work and keep up his role as a competent employee. He has asked Mira and Katri to use Finnish instead of English with him because he would like to take advantage of the opportunities to use Finnish at work. As the supervisors are really busy and their visits to the workplace are short, it might be that Kifibin does not want to cause too much trouble or take up too much of their time. When I asked Katri why she does not also give the instructions to the cleaners in writing - which would be reasonable and easy because clients often send their timetables and tasks via email - she simply told me that they prefer giving them orally and then reminding employees of them later on.

Although Kifibin's supervisors provide scaffolding when they are with him, they are not around on a daily basis. Kifibin works alone in the client's business premises, isolated from his workmates, able to ask for help only via the phone. For these reasons, it would be important that the supervisors and the cleaner would reach a proper agreement on the tasks face to face.

\subsection{Mae Noi's and Omar's workplace: The social action of organising shifts}

\subsubsection{The cleaning team's coffee room as a social nexus point}

This section (4.2) focuses on Mae Noi's and Omar's cleaning team. They have permanent jobs in a specialist organisation that directly employs its own cleaning staff. Their team consists of five cleaners, three of them native Finnish speakers. They usually have morning shifts from 6 a.m. to 2 p.m., sometimes evening shifts from 2 p.m. to 8 p.m. The cleaning areas consist of offices, corridors, toilets, and kitchens. Office and restaurant workers are present every day while they are cleaning. The cleaners have their own cleaning areas, where they may have short chats with other employees, but they perform their actual cleaning jobs individually, not in pairs or teams. However, they meet each other in the coffee room for coffee and lunch breaks. Because there is also a locker room behind the coffee room, they go there first thing in the morning and last thing in the afternoon. They also have their team meetings there approximately once a month. It is the material nexus where all the social actions in this section are located. 


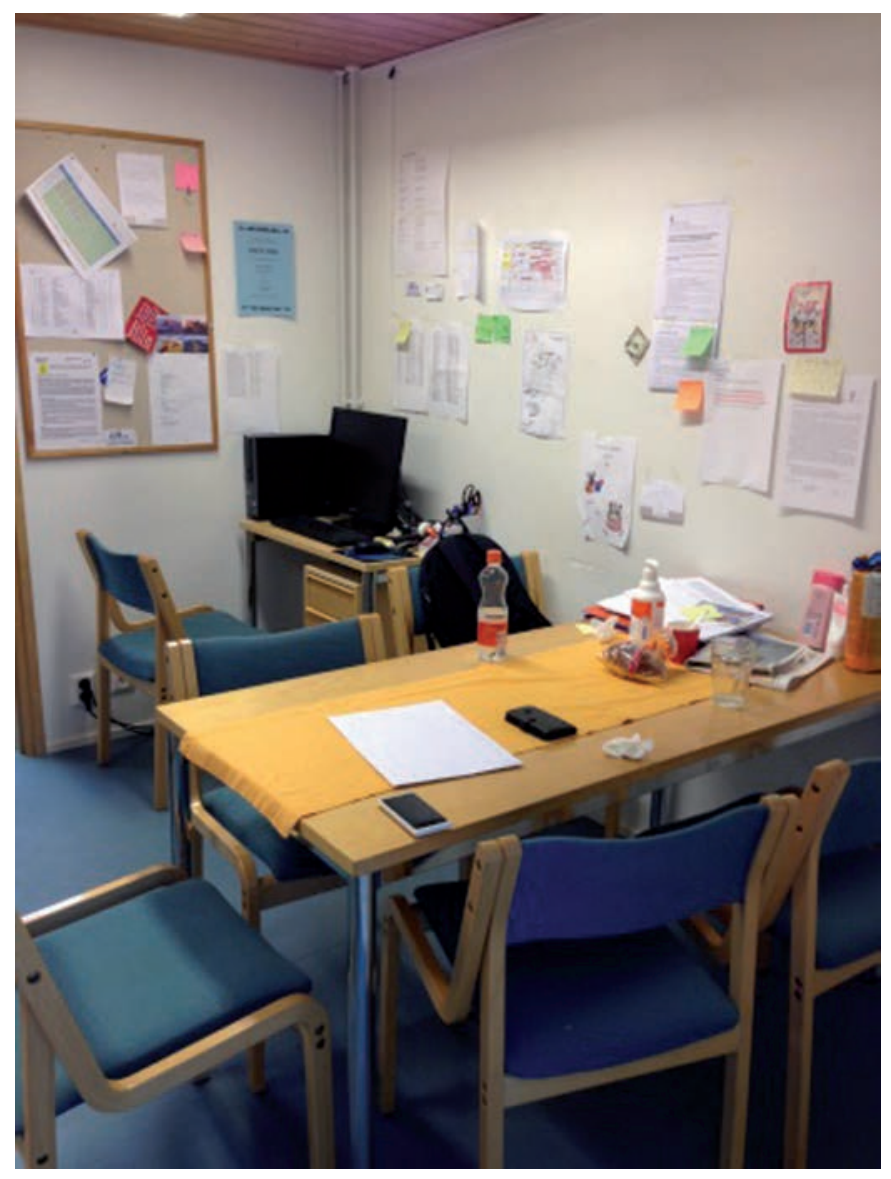

Figure 4: The table in the cleaners' coffee room.

The coffee room (see Figure 4) is a relatively small and intimate space that includes a dining table, a computer desk and kitchen equipment (a fridge, an oven, a sink; not visible in the picture). This place enables and even facilitates interaction between the team members: it is a peaceful and closed 'in-group' space to which only the team members have access (see Benwell and Stokoe 2006: 114). Therefore their interaction is not usually interrupted by noise or outsiders. Moreover, the room is open to wide range of formal and informal social actions, so it is relatively 'loosely controlled place', which refers to places that do not control actions strictly (Scollon and Scollon 2003: 169). During coffee and lunch breaks the cleaning team often talks about their free-time, family and other informal issues, but they also organise their work tasks and shifts then, since they 
are all together in the same place. As there is a computer in the room, breaks are sometimes also used for work-related tasks that require the use of a computer.

\subsubsection{Using a calendar as a mediational means in negotiating on work shifts}

This section explores the social action of Omar and his Finnish workmate Maarit changing their shifts (see Figure 5). Omar is a 50-year-old man who moved from Gambia to Finland in 2001 to marry a Finnish woman. First he attended Finnish language courses and integration training for adult immigrants and had practical training and summer jobs in a factory. However, he was not able to continue there and he therefore started to do cleaning jobs. He worked in five cleaning companies in two cities in Finland before getting a permanent position in the organisation where he currently works. His Finnish language skills are at the intermediate level (B1 in CEFR). In the following example, other cleaners, namely Maarit, Kirsi, and Sirpa, and their cleaning supervisor Mari, are also present. All the others are women whose mother tongue is Finnish.

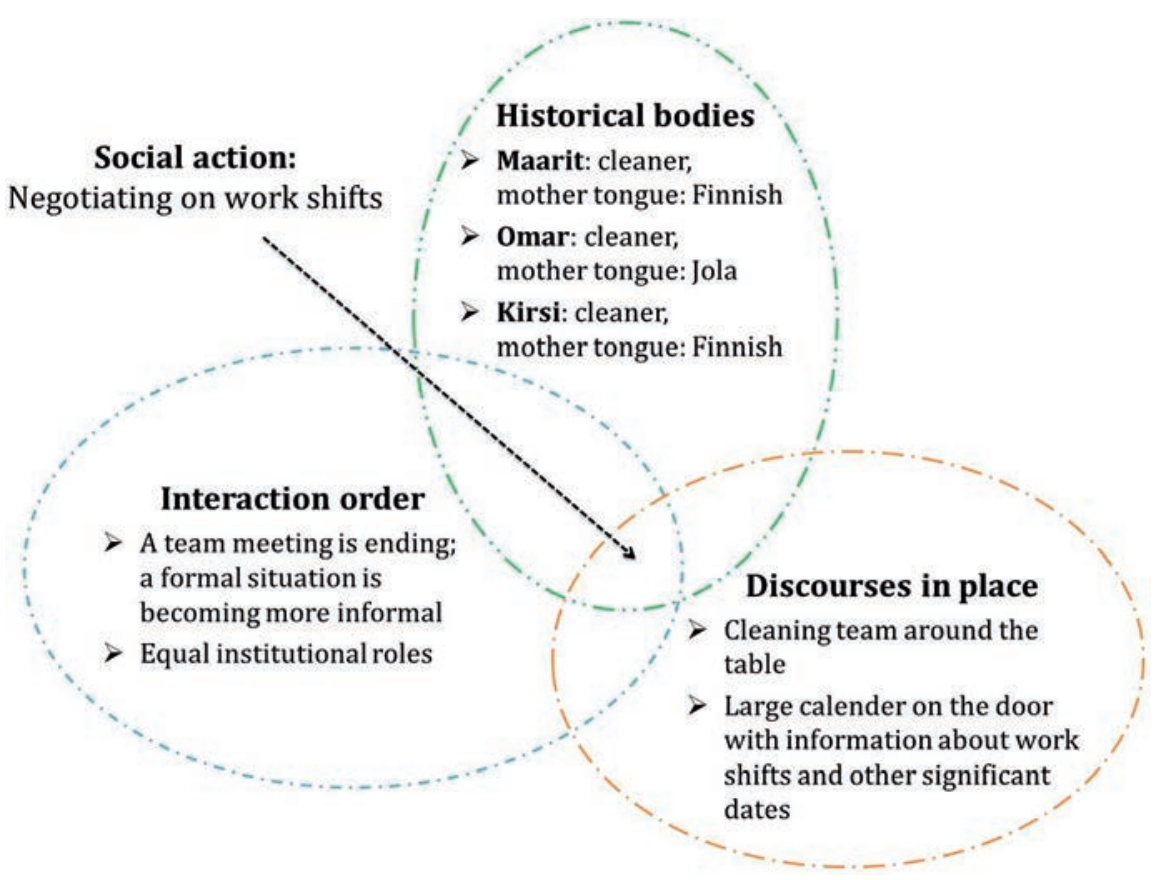

Figure 5: Nexus of changing work shifts (Application from Scollon \& Scollon 2004: 20). 
The next example takes place in the coffee room, where a calendar on the door (see Figure 6) is used a lot as a material artefact in mediating the scaffolding process. The interaction order is on the border of formal and informal: the team meeting led by Mari is ending, and the topic of conversation - shifts - is not on the agenda. On the one hand, the interaction order is equal between Omar and Maarit as far as their similar status is concerned: they are both cleaners. However, their historical bodies differ a lot as Omar moved to Finland 15 years ago and Maarit was born in Finland. Omar speaks Finnish as his second language, which is evident in this example: the team members adapt the conversation so that he can follow it.

The team meeting started directly after lunch in the coffee room. Omar, Maarit, Kirsi, and Sirpa were sitting round the table and Mari was sitting at the computer. I was sitting behind the video camera in the corner facing the table, recording the meeting. Sirpa had brought ice cream and they were still eating it when the meeting began. Mari read the agenda on the computer and Kirsi wrote notes for the record. They talked about window cleaning, ordering supplies, and training dates. They used some time figuring out when Mae Noi would come back from her vacation and how they would manage to clean her area properly before that. After 30 minutes they had dealt with all the formal issues and decided the date for the next meeting. At this point, Maarit stood up and went towards the calendar on the door. Suddenly she seemed to realise something and asked Omar if he could change the evening shifts with her.

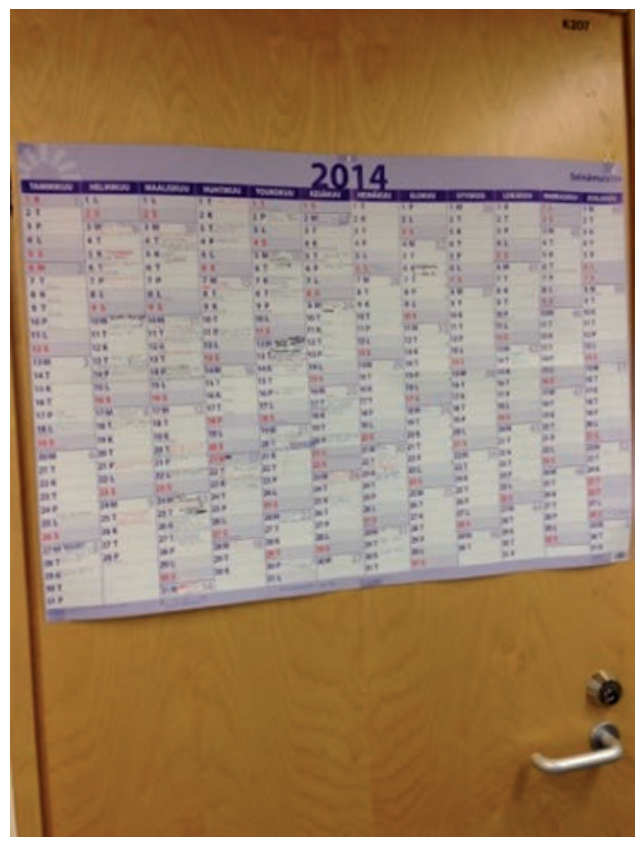

Figure 6: Calendar on the door of the coffee room. 
Excerpt 5: Changing shifts.

Participants: Maarit (cleaner, Finnish, female), Omar (cleaner, Gambian, male), Kirsi (cleaner, Finnish, female), Sirpa (cleaner, Finnish, female), Mari (cleaning supervisor, Finnish, female), Maiju (researcher, Finnish, female).

Data: video-recording and notes based on ethnographic observations.

\begin{tabular}{|c|c|c|}
\hline 01 & & $\begin{array}{l}\text { ((Maarit is standing in front of the calendar. Omar, Kirsi and Sirpa are sitting } \\
\text { round the table.)) }\end{array}$ \\
\hline \multirow[t]{2}{*}{02} & Maarit & hei [Omar] \\
\hline & & hey [Omar] \\
\hline 03 & & ((Omar, Kirsi and Sirpa look at Maarit.)) \\
\hline \multirow[t]{2}{*}{04} & Omar & no \\
\hline & & what \\
\hline \multirow[t]{2}{*}{05} & Maarit & haluaisitsä olla viikolla neljätoista \\
\hline & & in week fourteen would you like to be \\
\hline \multirow[t]{2}{*}{06} & Omar & mitä nii \\
\hline & & what \\
\hline \multirow[t]{2}{*}{07} & Maarit & $\begin{array}{l}\text { haluaisitsä olla viikolla neljätoista aamuvuorossa ja mää oisin viikolla } \\
\text { neljätoista iltavuorossa ja sä oisit viikolla *viistoista illassa ja mä oisin } \\
\text { aamussa (2.2) }\end{array}$ \\
\hline & & $\begin{array}{l}\text { would you like to take the morning shift in week fourteen and I would take the } \\
\text { evening shift in week fourteen and you would be on the evening shift in week } \\
\text { *fifteen and I would be on the morning shift (2.2) }\end{array}$ \\
\hline 08 & & $\begin{array}{l}\text { *((Kirsi turns to look at Omar and from now on looks continuously at Omar. } \\
\text { Omar looks at the calendar without saying anything and frowns.)) }\end{array}$ \\
\hline \multirow[t]{2}{*}{09} & Maarit & tä (1.6) oisko paha \\
\hline & & so (1.6) would it be bad \\
\hline 10 & & $\begin{array}{l}\text { ((Maarit moves from the calendar to the table. Kirsi glances at Maarit and } \\
\text { turns her gaze back to Omar again.)) }\end{array}$ \\
\hline \multirow[t]{2}{*}{11} & Kirsi & niin että vaihtaisitte päikseen iltavuorot \\
\hline & & so that you would change the evening shifts \\
\hline 12 & Maarit & $\mathrm{mhm}$ \\
\hline \multirow[t]{2}{*}{13} & Omar & sä halua me vaihtaa iltavuoro \\
\hline & & you want us to change the evening shift \\
\hline \multirow[t]{2}{*}{14} & Maarit & niin mieti sitä \\
\hline & & yeah think about that \\
\hline 15 & & ((Maarit goes to the calendar holding a pencil.)) \\
\hline \multirow[t]{2}{*}{16} & Omar & mil- hh \\
\hline & & whe- $h h$ \\
\hline
\end{tabular}


Excerpt 5: (continued)

\begin{tabular}{|c|c|c|}
\hline \multirow[t]{2}{*}{17} & Maarit & $\begin{array}{l}\text { elikkä sulla on viikolla neljätoista iltavuoro ja mulla ois viikolla viistoista (1.3) } \\
\text { ni (2.5) haluaisitsä vaihtaa mieti haluaisitsä vaihtaa nää (1.7) pä- niiku } \\
\text { päikseen ((naputtaa sormellaan kalenteria muutaman kerran osoittaen } \\
\text { ajankohtaa)) }\end{array}$ \\
\hline & & $\begin{array}{l}\text { well you have the evening shift in week fourteen and I would have it in week } \\
\text { fifteen (1.3) so (2.5) would you like to change think if you would like to change } \\
\text { these (1.7) with each other ((taps the calendar a few times with her finger } \\
\text { pointing at the dates)) }\end{array}$ \\
\hline \multirow[t]{2}{*}{18} & Maarit & elikkä mä oisin viik- tuolla sun viikolla \\
\hline & & so I would be in wee- in this your week \\
\hline \multirow[t]{2}{*}{19} & Omar & joo \\
\hline & & yeah \\
\hline \multirow[t]{2}{*}{20} & Maarit & ja sä olisit tolla (1.1) mieti (.) ilmota mulle sitte (2.5) \\
\hline & & and you would be in that (1.1) think about it (.) let me know then (2.5) \\
\hline \multirow[t]{2}{*}{21} & Maarit & sillo ois kaikki (poissa) ja mä [saisin Sirpan kanssa \\
\hline & & then everybody would be (absent) and I [could with Sirpa \\
\hline 22 & Omar & [mä oon neljäs neljästoista viikko \\
\hline
\end{tabular}

23 Sirpa $\quad[$ nii

[yeah

24 Maarit $[\mathrm{mhm}$

25 ((Maarit goes to sit at the table. Maarit, Omar and Sirpa are looking at the calendar. Kirsi is still looking at Omar.))

26 Omar jaa mitä on onko se kolmekymmentä (.) kolmekymmentäyks well so is it thirty (.) thirty-one

\begin{tabular}{rrr}
\hline 27 & Maarit $\quad[$ kolmeyks (.) joo \\
& {$[$ thirty-one (.) yeah }
\end{tabular}

28 Omar ja menee and it goes

29 Maarit huhtikuun alkuun (3.1) sulla ois sitte till the beginning of April (3.1) you would then have

30 Omar ja sinä on viistoista (.) okei mä otan viistoista ja sä et and you are fifteen (.) okay I take fifteen and you don't ((Maarit stands up and moves back to the calendar.)) 
The higher-level action here - changing shifts - is quite simple, but it requires a lot of negotiation, a long chain of lower-level actions, before the issue is settled. In line 7, Maarit asks if Omar could change his evening shifts with her. Omar takes a look at the calendar on the door and looks thoughtful (line 8). Maarit reacts to the silence by asking if it would be bad (line 9) and moves towards the table. Kirsi forms Maarit's question in other words, putting it more briefly and simply, in line 11, and Omar makes sure that he has understood Maarit's suggestion correctly (line 13). Maarit confirms it (line 14) and goes back to the calendar (line 15). Since Omar still seems to be unsure (line 16), Maarit repeats the suggestion in line 17 and shows the weeks concretely by pointing to them on the calendar. Omar says the week out loud (line 22) and then asks about the date (line 26). At this point, Maarit has come to the table too (line 25) and is looking towards the calendar with Omar and Sirpa. She confirms the date (line 29) and finally, in line 30, Omar accepts the suggestion. After that, Maarit stands up and goes to the calendar again to record the result of the conversation (line 31).

The calendar seems to be a significant mediational means in the conversation because Sirpa's gaze is also fixed on it. Kirsi, on the other hand, attends to Omar during most of the conversation by looking at him, also when Maarit is speaking and when Omar is looking somewhere else. Even in line 25 when everybody else visible on the video (Omar, Maarit and Sirpa) direct their attention and gaze towards the calendar, Kirsi's gaze is directed at Omar's face. This is unusual, as the co-workers typically attend to the same object by 'collaborative viewing' if the object is made relevant in work-related interaction (Hindmarsh and Heath 2000: 540). It seems as Kirsi would be checking Omar's comprehension by monitoring his facial expressions - the team members told me that they learn to see when second language users have not understood something. Maarit and Sirpa said in an interview that they use as much time as is needed to achieve mutual understanding with team members because it is more of a problem if an issue remains unclear. Not all the conversations with Omar contain as much scaffolding as this one - usually he follows the conversation easily.

From the ecological perspective, this example shows how the physical environment and the material artefact - the calendar on the door - serve as material scaffolding. The team members perform many lower-level actions with the calendar in this team meeting. Maarit makes her suggestion more concrete by pointing to the dates on the calendar and the attention of the whole team is directed at the calendar when they are trying to make sense of the shifts. After the excerpt presented above, Kirsi goes to the calendar to check when the training week is and Sirpa goes and checks when she has an evening shift. After that, Omar goes up to the calendar to read what is written there, too. The texts and times on the calendar are used as affordances in conversations, and because the decisions are 
written on the calendar, they become frozen actions (Norris 2004: 102) visible for anybody who checks it. Some of the team members use electronic calendars on their smart phones, too, but the calendar on the door is a common resource for all the team members. The fact that they use the calendar so much shows that dates and times are important to them when they are organising the team members' work. Also de Saint-Georges (2004) noted that anticipatory discourse in the form of schedules is common in cleaning work.

\subsubsection{Embodied co-construction of knowledge: Filling in an electronic form}

This section explores how Maarit provides material scaffolding to her co-worker Mae Noi when they are filling in an electronic form together (see Figure 7). Mae Noi is a 40-year-old woman who moved from Thailand to Finland in 2005 in order to get married. She has attended Finnish integration training for adult immigrants and worked in restaurants as a cook and a waitress. Before getting a permanent position as a cleaner, she cleaned hotels. In Thailand, she studied to be a masseur and in Finland she also has a massage business. Using a computer is a practice that has not (yet) fully become part of her personal experience and historical body. In the interview, Mae Noi brought out that she would like to learn to use a computer because it is necessary in her job, but she still needs to ask for help. Maarit, in contrast, is confident with computer programmes and electronic forms. She is an informal support person for Omar and Mae Noi, probably because she has worked in the team longer than the other Finnish cleaners, and from the beginning, like Omar and Mae Noi. Thus she best understands their way of speaking Finnish.

The social action takes place in the coffee room after a lunch break. The interaction order changes from informal lunch-time conversations to work-related issues. Several technical tools - a computer, an electronic form, a keyboard, and a mouse- are utilised to mediate the scaffolding process. The social surroundings offer affordances for the social action, too, and in the next example Maarit offers many affordances by sharing her computational and literacy skills in Finnish and English with Mae Noi in the scaffolding process. 


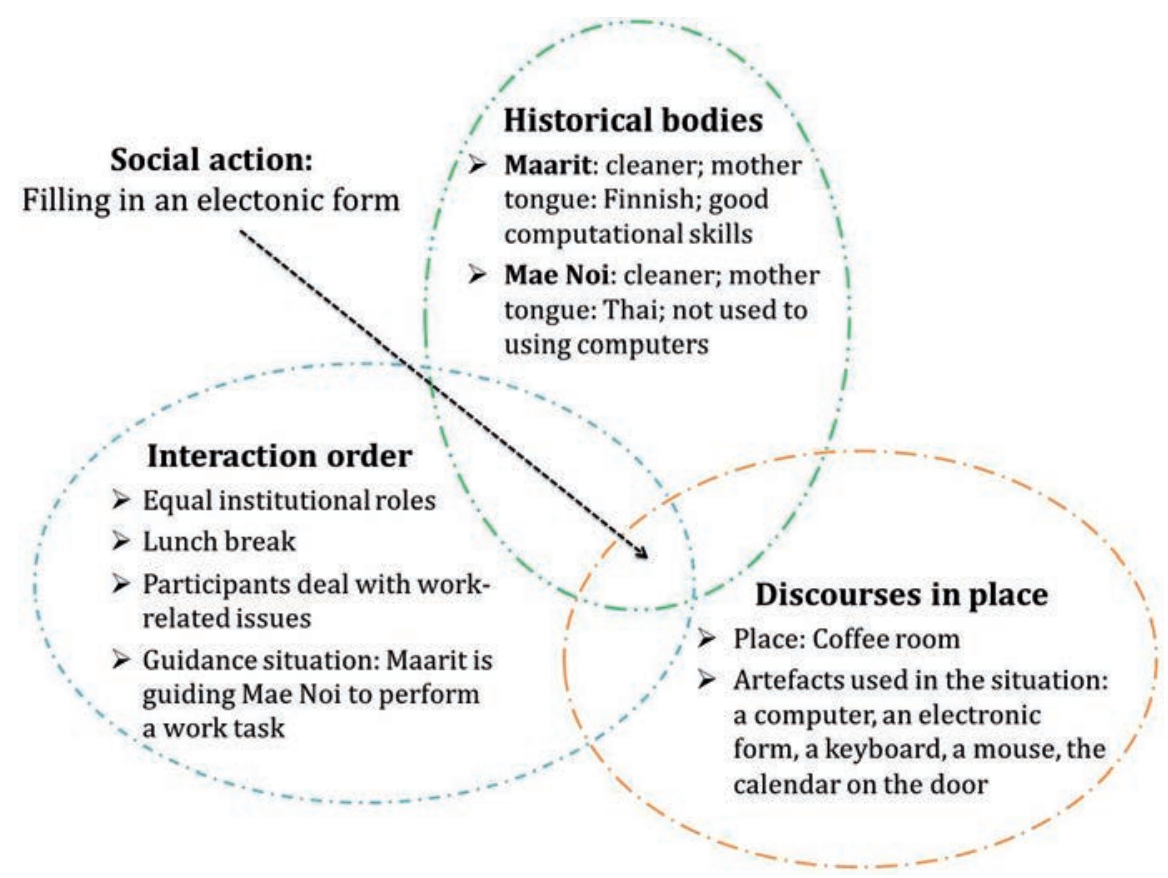

Figure 7: Nexus of filling in an electronic form (Application from Scollon \& Scollon 2004: 20).

Mae Noi, Omar, Maarit and an intern, a young Finnish man called Elias, were eating lunch in the coffee room. First they talked about their free-time activities and holidays. After lunch they had coffee and started to talk about work-related issues, namely about filling in applications for leave. It was a practice they needed to perform because their manager used to check the applications and confirm them online. First Omar remembered that he had not applied for any holiday yet, but he seemed to be unsure when to take it. After that, Mae Noi asked Maarit to help her with filling in an electronic application. Mae Noi sat down in front on the computer and Maarit came to help her. Maarit stood behind her and watched the screen. I was sitting next to Omar and faced the computer so that I could see both the women filling in the form. I watched and wrote field notes while they carried out the task. 
Excerpt 6: Applying for leave using an electronic form.

Participants: Mae Noi (cleaner, Thai, female), Maarit (cleaner, Finnish, female), Omar (cleaner, Gambian, male), Maiju (researcher, Finnish, female), Elias (intern, Finnish, male) ${ }^{2}$

Data: audio-recording and notes based on ethnographic observations.

\begin{tabular}{|c|c|c|}
\hline \multirow[t]{2}{*}{01} & \multirow[t]{2}{*}{ Mae Noi } & \multirow{2}{*}{$\begin{array}{l}\text { tää ensimmäinen } \\
\text { this first one }\end{array}$} \\
\hline & & \\
\hline 02 & Maarit & $\mathrm{mhm}$ \\
\hline 03 & & (2.3) ((Mae Noi clicks the link.)) \\
\hline \multirow[t]{2}{*}{04} & Maarit & sit kirjauvvu taas sinne \\
\hline & & then log in again there \\
\hline 05 & & $\begin{array}{l}\text { (22.1) ((Mae Noi types her user name and password. It takes } 22 \text { seconds. At } \\
\text { this point, there is a short conversation about Omar's leave, too.)) }\end{array}$ \\
\hline \multirow[t]{2}{*}{06} & Mae Noi & mikä se on \\
\hline & & what's that \\
\hline \multirow[t]{2}{*}{07} & Maarit & $\begin{array}{l}\text { ((Maarit reads the message on the screen)): sinun Java-versiosi on } \\
\text { päivittämätön (.) update (1.5) oota (.) continue and you will remind it up- (.) pistä } \\
\text { later (.) pistä later }\end{array}$ \\
\hline & & $\begin{array}{l}\text { ((Maarit reads the message on the screen)): your Java version is not updated (.) } \\
\text { update (1.5) wait (.) continue and you will remind it up-(.) choose later (.) } \\
\text { choose later }\end{array}$ \\
\hline \multirow[t]{2}{*}{08} & Mae Noi & tämä \\
\hline & & this one \\
\hline \multirow[t]{2}{*}{09} & Maarit & joo \\
\hline & & yes \\
\hline 10 & & (1.0) ((Mae Noi clicks this option.)) \\
\hline \multirow[t]{2}{*}{11} & Maarit & muista vaan päivittää se sitten (.) sitten run (3.0) joo'o \\
\hline & & yes (.) you just need to remember to update it then (.) then run (3.0) yes \\
\hline 12 & & (1.9) ((Mae Noi clicks the mouse.)) \\
\hline \multirow[t]{2}{*}{13} & Maarit & vielä kerran run \\
\hline & & once more run \\
\hline 14 & & (6.1) ((Mae Noi clicks the mouse.)) \\
\hline \multirow[t]{2}{*}{15} & Maarit & sitten vuosilomat (2.2) \\
\hline & & then annual leave (2.2) \\
\hline
\end{tabular}

2 Omar and Elias have simultaneous discussions that are audible on the tape, but these turns are not shown in the transcription for the sake of clarity. 
Excerpt 6: (continued)

\begin{tabular}{|c|c|c|}
\hline 16 & Mae Noi & missä pää- \\
\hline & & where the main- \\
\hline \multirow[t]{2}{*}{17} & Maarit & vasemmalla (.) siinä \\
\hline & & on the left (.) there \\
\hline \multirow[t]{2}{*}{18} & Mae Noi & tämä \\
\hline & & this one \\
\hline \multirow[t]{2}{*}{19} & Maarit & joo \\
\hline & & yeah \\
\hline 20 & & ((Mae Noi clicks.)) \\
\hline \multirow[t]{2}{*}{21} & Maarit & ja avaa \\
\hline & & and open \\
\hline 22 & & (4.4) ((Mae Noi clicks.)) \\
\hline \multirow[t]{2}{*}{23} & Maarit & $\begin{array}{l}\text { sit sinne pitäs laittaa alku- alkupäivä elikkä sä olit viikon (1.5) siis olitko sä nyt } \\
\text { sitten vii- }\end{array}$ \\
\hline & & $\begin{array}{l}\text { then you must put the starting date so you've had a week (1.5) so did you have a } \\
\text { wee- }\end{array}$ \\
\hline \multirow[t]{2}{*}{24} & Mae Noi & kaksyksi \\
\hline & & twenty-one \\
\hline \multirow[t]{2}{*}{25} & Maarit & kaksyks viikolta alot- \\
\hline & & starting from week twenty-one \\
\hline \multirow[t]{2}{*}{26} & Mae Noi & joo (.) maanantaina (.) voin kirjostaa \\
\hline & & yes (.) on Monday (.) I can (write) \\
\hline
\end{tabular}

In this excerpt, the interaction order is a hierarchical novice-expert situation: Mae Noi waits for Maarit's advice before proceeding with the form and clicking the links. Going to the computer and logging in to the system combine an opening to the higher-level action of filling in the form. The opening is followed by a specific pattern of lower-level actions that is repeated many times: Maarit's verbal instructions followed by Mae Noi's embodied actions (lines 4-5, 11-12 and 13-14, and 21-22). Mae Noi follows the orders with actions, not words. Therefore, the noticeable silences between Maarit's turns are not gaps in accomplishing the higher-level action but instead they are filled with lower-level actions, namely clicking the links (lines 3,10,12,14, 22), which is necessary in moving on in the electronic form. Materiality is evident as the keyboard and the mouse are used as mediational means to co-construct meanings on the electronic form, and the cursor is used to navigate the way through the different steps on the form. Mae 
Noi uses her cursor as an indicator and asks Maarit to confirm if it is in the right place before clicking the link in lines 1, 8 and 18 .

Maarit provides scaffolding for Mae Noi by many overlapping lower-level actions. Maarit's bodily orientation displays a strong alignment to the electronic form: she stands right behind Mae Noi and looks at the screen (see also Hindmarsh and Heath 2000: 540). From that position, she gives verbal and embodied advice on where to click and reads the message that pops up on the screen (line 7). Writing and reading Finnish, especially typing on the computer, is challenging for Mae Noi. However, she writes down her user name and password on her own (line 5), which is a repeated practice and therefore part of her historical body: the employees in the organisation need to do it every time they use a computer. After Excerpt 5, Mae Noi enters the starting and finishing dates of her holiday, too, but this time with Maarit's help. The calendar on the door serves as an affordance when writing the dates. This part of the transcription is not presented here because of its length: it takes 1 minute 10 seconds ( 25 turns) to type the dates on the keyboard. Maarit guides the writing by saying out loud how to write the date (zero eight comma etc.) and Mae Noi follows step by step. Once the dates are successfully on the form, Mae Noi indicates by her body position that she would like Maarit to write the longer text to the manager:

Excerpt 7: Writing a message.

\begin{tabular}{|c|c|c|}
\hline 01 & Mae Noi & missä nyt (.) tässä näin \\
\hline & & where now (.) this one here \\
\hline \multirow[t]{2}{*}{02} & Maarit & $\begin{array}{l}\text { siinä (1.5) ja sitten pistät vaikka viestin vastaanottajalle että hei (1.3) loma- } \\
\text { anomus ((nauraa)) hei [esimies] loma-anomukseni }\end{array}$ \\
\hline & & $\begin{array}{l}\text { there (1.5) and then send a message to the recipient that hi (1.3) my application } \\
\text { for leave ((gives a laugh)) hi [manager] my application for leave }\end{array}$ \\
\hline 03 & & (4.3) ((Mae Noi moves her upper torso.)) \\
\hline \multirow[t]{2}{*}{04} & Mae Noi & entä muuta (4.0) \\
\hline & & and something else (4.0) \\
\hline \multirow[t]{2}{*}{05} & Maarit & kato \\
\hline & & look \\
\hline 06 & & $\begin{array}{l}\text { (16.5) ((Maarit leans over the keyboard and writes the message. Then she } \\
\text { starts to laugh.)) }\end{array}$ \\
\hline \multirow[t]{2}{*}{07} & Maarit & anteeks ((nauraen)) (1.6) onko nyt hyvä \\
\hline & & sorry ((laughing)) (1.6) is it good now \\
\hline \multirow[t]{2}{*}{08} & Mae Noi & joo \\
\hline & & yes \\
\hline
\end{tabular}


Excerpt 7: (continued)

\begin{tabular}{lll}
\hline 09 & Maarit & sitten vaan lähetät sen siitä \\
\hline 10 & & then you just send it there \\
\hline 11 & Maarit & joo (.) ja sitten katotaan vielä (1.4) joo sitten jatkat \\
\hline & yes (.) and then let's take a look at (1.4) yes and then you continue \\
\hline $\mathbf{1 2}$ & & (2.6) ((Mae Noi clicks.)) \\
\hline $\mathbf{1 3}$ & Maarit & nyt siinä lukee että ehdotettu (.) ja nyt se on menny [esimiehelle] \\
\hline & & and now it reads it's proposed (.) and now it's gone [to the manager]
\end{tabular}

14 Mae Noi mhm

It takes over 5 minutes to perform this higher-level action of filling in the form. The last step is to write a message to the manager who accepts (or rejects) the applications, and Mae Noi gives Maarit a lot of power, which shows Mae Noi's trust in her close colleague. In line 2, Maarit seems to propose to Mae Noi that she should write the message on her own, but by turning away Mae Noi signals to Maarit that she would like her to write it. Maarit leans over Mae Noi's shoulder to type, which seems to be confusing for her as she laughs and apologises (lines 67). In Finland, people expect their personal space to be quite large and independence is much appreciated at work, and so Maarit might feel a bit unsure about writing the message on Mae Noi's behalf even though she is used to providing her with scaffolding in many of the tasks she has to do at work. The filled electronic form with the message attached to it becomes a frozen action, a material manifestation of the scaffolding situation (Norris 2004), but reveals only a small part of it. The manager will only see the end product, in which Maarit's contribution remains invisible.

Based on the analysis of the ethnographic and interactional data collected at these two work sites, it is evident that cleaning work does not necessarily require fluent language skills in the working language of the cleaning organisation if material scaffolding is available. Computational tasks might turn out to be the most challenging part of the working routine, and appropriate support and training should be offered. Mae Noi and Omar appreciate the fact that they now work within a familiar team that is always present and available to offer support which was not the case in their previous cleaning workplaces. 


\section{Conclusions}

The aim of this paper was to analyse material scaffolding in cleaning work. The ethnographic discourse analysis shows that the more concrete the situation is and the more material mediational means available for scaffolding in the surroundings there are, the easier it is for these speakers of Finnish as a second language to understand and follow instructions. In addition to utilizing material artefacts in physical places, these colleagues also provided embodied scaffolding, by using gaze to monitor comprehension and by pointing to direct attention to the significant elements for the task in hand.

The recent flow of asylum seekers to Europe mean more migrant employees in the workplaces of many European countries. In Finland, refugees' quick entry to the labour market is emphasized as an important goal in the integration policy. The practical aim of the paper was to offer good practices and advice for multilingual work communities. This study suggests that it is possible to manage in cleaning work in a new country even if one is still in the early stages of learning the local language(s) as long as scaffolding is provided. Work communities should be encouraged to use the local language(s) of the country within multilingual teams as knowledge of a majority language facilitates integration into society. Besides verbal scaffolding to help support migrants' language skills, several material scaffolding strategies can be employed in communication. It is evident that the participants in this study are used to working with second language speakers and have learned different ways of communicating with them efficiently and effectively. They know how to demonstrate the work task and utilize body, gaze, space and material artefacts in communication. They also reported that they try to speak slowly, repeat themselves, and check if the migrants have understood. The results suggest that the biggest challenge is to ensure that tasks are understood if cleaners work on their own without any immediate support available in their workplaces. When managers allocate cleaners to workplaces and decide who they will work with, they could usefully take this into account. As the cleaning industry is highly competitive, breakdowns in communication are not a good selling point.

From the pedagogical perspective, balancing is required in order to provide an optimal amount of scaffolding (see also Suni 2008: 117-118). Gradually scaffolding strategies should be reduced and learners should be encouraged to manage on their own whenever possible because too heavy support may reduce learning opportunities. For instance, language use that is too concrete and deictic may inhibit vocabulary learning, like in Excerpt 1, in which the cleaning supervisor never mentions the word 'floor tile' in Finnish (see also Sandwall 2010: 559). The challenge is to provide enough scaffolding to make sure workers perform 
their work properly but not so much as to prevent them from becoming independent employees.

This study offers some discoveries on the spatial aspects of communication, but more research is needed to understand the constraints and affordances the physical layout sets for communication in different settings. It seems that some places, such as stairways, restrict communication because not all the material and embodied modes of communication can be employed there; other places, such as coffee rooms, offer more affordances for meaningful interaction. Coffee rooms can offer social nexuses, in other words, rich 'semiotic budgets' (van Lier 2004), for scaffolding language learning.

Acknowledgements: I am grateful to the participants and their organizations for making this study possible. I would like to express my gratitude to Minna Suni, Sari Pietikäinen and the second anonymous reviewer for their valuable comments. In addition, I want to thank my peers who read and discussed the paper with me during different phases of the writing process - it was truly helpful.

\section{Appendices}

\section{Appendix 1: Transcription}

(.)

\section{((lifts a floor tile))}

mil-

[

$\underline{\text { small }}$

?

[in a restaurant] pause in speech (less than 1 second)

silences timed in tenths of a second

explanations of actions and sounds

cut-off word

beginnings of simultaneous talk

emphasis

rising intonation at the end of the prosodic entity

changed names and blurred details

\section{References}

Al Zidjaly, Najma. 2006. Disability and anticipatory discourse: The interconnectedness of local and global aspects of talk. Communication \& Medicine 3(2). 101-112.

Barab, Sasha \& Wollf-Michael Roth. 2006. Curriculum-based ecosystems: Supporting knowing from an ecological perspective. Educational Researcher 35(5). 3-13.

Carter, Glenda, Eric Wiebe, Angelia Reid-Griffin \& Susan Butler. 2006. Gestures: Silent scaffolding within small groups. Journal of classroom interaction 41(1). 15-21. 
Compton, Sarah. 2013. Implementing language policy for deaf students in a Texas school district. International Multilingual Research Journal 7(2). 138-154.

Crabtree, Andy. 2000. Remarks on the social organization of space and place. Journal of mundane behavior 1(1). http://mundanebehavior.org/category/issues/issue-1-1 (accessed 18 March 2016)

de Saint-Georges, Ingrid. 2004. Materiality in discourse: The influence of space and layout in making meaning. In Philip Levine \& Ron Scollon (eds.), Discourse \& Technology: Multimodal Discourse Analysis, 71-87. Washington D.C.: Georgedown University Press.

Dlaske, Kati. 2015. Discourse matters: Localness as a source of authenticity in craft business in peripheral minority language sites. CADAAD Journal 7(12). 243-262.

Duchêne, Alexandre, Melissa Moyer \& Celia Roberts. 2013. Language, migration and social inequalities: A critical sociolinguistic perspective on institutions and work. Bristol: Multilingual Matters.

Dufva, Hannele, Minna Suni, Mari Aro \& Olli-Pekka Salo. 2011. Languages as objects of learning: Language learning as a case of multilingualism. Apples - Journal of Applied Language Studies 5(1).109-124. http://apples.jyu.fi/article_files/v5-8_Dufva_et_al_final.pdf (accessed 25 September 2015)

Erickson, Frederick. 1986. Qualitative methods. Research in Teaching and Learning 2. New York: Macmillan Publishing Company.

Filliettaz, Laurent. 2013. Affording learning environments in workplace contexts: an interactional and multimodal perspective. International Journal of Lifelong Education 32(1). 107-122.

Gibson, James. 1979. The ecological approach to visual perception. Boston: Houghton Mifflin.

Goodwin, Charles. 2000. Action and embodiment within situated human interaction. Journal of Pragmatics 32(10). 1489-1522.

Goodwin, Charles. 2013. The co-operative, transformative organization of human action and knowledge. Journal of Pragmatics 46(1). 8-23.

Gullberg, Marianne. 2006. Some reasons for studying gesture and second language acquisition (Hommage à Adam Kendon). International Review of Applied Linguistics in Language Teaching 44(2). 103-124.

Hakamäki, Leena. 2005. Scaffolded assistance provided by an EFL teacher during whole-class interaction. Jyväskylä Studies in Humanities 32. Jyväskylä: University of Jyväskylä.

Hanjani, Alireza Memari \& Li Li. 2014. Exploring L2 writers' collaborative revision interactions and their writing performance. System 44 (1). 101-114.

Heath, Christian \& Paul Luff. 2013. Embodied action and organisational interaction: Establishing contract on the strike of a hammer. Journal of Pragmatics 46(1). 24-38.

Hindmarsh, Jon \& Christian Heath. 2000. Sharing the tools of trade: The interactional constitution of workplace objects. Journal of Contemporary Ethnography 29(5), 523-562.

Huang Yong-Ming \& Yueh-Min Huang. 2015. A scaffolding strategy to develop handheld sensorbased vocabulary games for improving students' learning motivation and performance. Educational Technology Research and Development 63(5). 691-708.

Hult, Francis. 2010. Analysis of language policy discourses across the scales of space and time. International Journal of the Sociology of Language 202. 7-24.

Hult, Francis. 2014. Covert bilingualism and symbolic competence: Analytical reflections on negotiating insider/outsider positionality in Swedish speech situations. Applied Linguistics 35(1). 63-81. 
Izadi, Dariush. 2015. Spatial engagement in Persian ethnic shops in Sydney. Multimodal Communication 4(1). 61-78.

Jefferson, Gail. 1989. Preliminary notes on a possible metric which provides for a 'standard maximum' silence of approximately one second in conversation. In Derek Roger \& Peter Bull (eds.), Conversation, 166-196. Clevedon: Multilingual Matters.

Jones, Rodney \& Sigrid Norris. 2005. Discourse as action/discourse in action. In Sigrid Norris \& Rodney Jones (eds.), Discourse in action. Introducing mediated discourse analysis, 3-14. New York: Routledge.

Jung Insung \&Yoko Suzuki. 2015. Scaffolding strategies for wiki-based collaboration: Action research in a multicultural Japanese language program. British Journal of Educational Technology 46(4). 829-838.

Koschmann, Timothy, Curtis LeBaron, Charles Goodwin \& Paul Feltovich. 2006. The mystery of the missing referent: Objects, procedures, and the problem of the institutional follower. CSCW' 06 Proceedings of the $200620^{\text {th }}$ anniversary conference on computer supported cooperative work, 373-382, New York: ACM.

Kramsch, Claire \& Sune Von Steffensen. 2008. Ecological perspectives on second language acquisition and language socialization. In Patricia Duff \& Nancy Hornberger (eds.), Encyclopedia of Language and Education 8, 17-28. Dordrecht: Springer Verlag.

Källkvist, Marie. 2013. The engaging nature of translation: A nexus analysis of student-teacher interaction. In Dina Tsagari \& Georgios Floros (eds.), Translation in language teaching and assessment, 115-134. Newcastle: Cambridge Scholars Publishing.

Lane, Pia. 2010. "We did what we thought was best for our children": A nexus analysis of language shift in a Kven community. International Journal of the Sociology of Language 202. 63-78.

Lehtonen, Tuija. 2013. Tuen muodot ja oppimisen mahdollisuudet suomen kielen verkkokurssilla [scaffolding and affordances in the Finnish as a foreign language web course]. Lähivõrdlusi. Lähivertailuja 23. 163-186.

Lerner, Gene. 2002. Turn-sharing: the choral co-production of talk-in-interaction. In Cecilia Ford, Barbara Fox \& Sandra Thompson (eds.), The language of turn and sequence, 225-256. Oxford: Oxford University Press.

Lilja, Niina. 2010. Ongelmista oppimiseen. Toisen aloittamat korjausjaksot kaksikielisessä keskustelussa [other-initiated repair sequences in Finnish second language interactions]. Jyväskylä studies in humanities 146. Jyväskylä: University of Jyväskylä.

Lier, Leo van. 2000. From input to affordance: Social-interactive learning from an ecological perspective. In James Lantolf (ed.), Sociocultural theory and second language learning, 245-260. Oxford: Oxford University Press.

Lier, Leo van. 2004. Ecology and semiotics of language learning: A sociocultural perspective. Boston: Kluwer Academic.

Nassaji, Hossain \& Merril Swain. 2000. A Vygotskian perspective on corrective feedback in L2: The effect of random versus negotiated help on the learning of English articles. Language Awareness 9(1). 34-51.

Nguyen, Minh Hue. 2013. EFL students' reflections on peer scaffolding in making a collaborative oral presentation. English Language Teaching 6 (4). 64-73.

Norris, Sigrid. 2004. Multimodal discourse analysis: a conceptual framework. In Philip Levine \& Ron Scollon (eds.), Discourse \& Technology: Multimodal Discourse Analysis, 101-115. Washington D.C.: Georgedown University Press.

Norris, Sigrid \& Rodney Jones (eds.). 2005a. Discourse in action: Introducing mediated discourse analysis. New York: Routledge. 
Norris, Sigrid \& Rodney Jones. 2005b. Introducing mediational means/cultural tools. In Sigrid Norris \& Rodney Jones (eds.), Discourse in action. Introducing mediated discourse analysis, 49-51. New York: Routledge.

Norris, Sigrid \& Rodney Jones. 2005c. Methodological principles and new directions in MDA. In Sigrid Norris \& Rodney Jones (eds.), Discourse in action. Introducing mediated discourse analysis, 201-206. New York: Routledge.

Official statistics of Finland (OSF). 2013. Employment [e-publication]. Industry, employer sector and jobs 2011, Appendix table 1. Most common occupational groups among employed persons aged 18 to 74 with foreign origin in 2011. Helsinki: Statistics Finland.

Orlikowski, Wanda. 2005. Material knowing: The scaffolding of human knowledgeability. Essay based on an address given to the Sixth European Conference on Organizational Knowledge, Learning, and Capabilities, Cambridge, MA in March 2005. http://seeit.mit.edu/Publication s/Orlikowski_OKLC_write-up_2006.pdf (assessed 21 October 2015).

Orlikowski, Wanda. 2007. Sociomaterial Practices: Exploring Technology at Work. Organization studies 28(9). 1435-1448.

Ozyegin, Gul \& Hondagneu-Sotelo, Pierette. 2008. Conclusion: Domestic work, migration and the new gender order in contemporary Europe. In Helma Lutz (ed.), Migration and Domestic Work: A European Pespective on a Global Theme. Ashgate Publishing Group.

Paananen, Jenny. 2015. Kuinka eleet helpottavat yhteisymmärrystä? Ikoniset ja deiktiset eleet monikulttuurisilla lääkärin vastaanotoilla [how does gesturing facilitate mutual understanding? Iconic and deictic gestures in multicultural general practice consultations]. Puhe ja kieli 35(2). 73-95.

Pietikäinen, Sari, Riikka Alanen, Hannele Dufva, Paula Kalaja, Sirpa Leppänen \& Anne PitkänenHuhta. 2008. Languaging in Ultima Thule: Multilingualism in the life of a Sami boy. International Journal of Multilingualism 5(2). 79-99.

Pietikäinen, Sari, Pia Lane, Hanni Salo \& Sirkka Laihiala-Kankainen. 2011. Frozen actions in the Arctic linguistic landscape: a nexus analysis of language processes in visual space. International Journal of Multilingualism 8(4). 277-298.

Pietikäinen, Sari. 2010. Sámi language mobility: Scales and discourses of multilingualism in a polycentric environment. International Journal of the Sociology of Language 202. 79-101.

Sandwall, Karin. 2010. "I learn more at school": A critical perspective on workplace-related second language learning in and out of school. Tesol Quarterly 44(3). 542-574.

Scollon, Ron. 2001. Mediated discourse: The nexus of practice. London: Routledge.

Scollon, Ron \& Suzie Wong Scollon. 2003. Discourses in place: Language in the material world. New York: Routledge.

Scollon, Ron \& Suzie Wong Scollon. 2004. Nexus analysis: Discourse and the emerging internet. London: Routledge.Simon-Maeda, Andrea. 2009. Working the hybridization: A case of biand multilingual speakers in Japan. International Multilingual Research Journal 3. 90-109.

Smit, Jantien, Henriëtte A. A. van Eerde \& Arthur Bakker. 2012. A conceptualisation of wholeclass scaffolding. British Educational Research Journal 39(5). 817-834.

Streeck, Jürgen, Charles Goodwin \& Curtis LeBaron (eds.). 2011. Embodied interaction: Language and body in the material world, 1-26. Cambridge: Cambridge University Press.

Strömmer, Maiju. 2016. Affordances and constraints: Second language learning in cleaning work. Multilingua. Published ahead of print in 2015. DOI: 10.1515/multi-2014-0113

Suni, Minna. 2008. Toista kieltä vuorovaikutuksessa. Kielellisten resurssien jakaminen toisen kielen omaksumisen alkuvaiheessa [second language in interaction: sharing linguistic 
resources in the early stage of second language acquisition]. Jyväskylä: University of Jyväskylä.

Suni, Minna. 2010. Työssä opittua: työntekijän näkökulma ammatilliseen kieli- ja viestintätaitoonsa [learned at work: an employee's perspective on their professional language and communicative skills]. In Mikel Garant \& Mirja Kinnunen (eds.), AFinLA-e: Soveltavan kielitieteen tutkimuksia 2, 45-58. Jyväskylä: Finnish association for applied linguistics. http://ojs.tsv.fi/index.php/afinla/article/view/3875 (assessed 21 October 2015).

Tapio, Elina. 2013. A nexus analysis of English in the everyday life of FinSL signers: A multimodal view on interaction. Jyväskylä: Jyväskylä University Printing House.

Trux, Marja-Liisa. 2002. Diversity under the northern star. In Annika Forsander (ed.), Immigration and economy in the globalization process: The case of Finland, 175-225. Helsinki: Sitra.

Virtanen, Aija. 2013. Minä sairaanhoitajana: tulevaisuuden minuudet motivaatiota muokkaamassa. Lähivertailuja - Lähivõrdlusi 23. 403-427. http://www.rakenduslingvistika.ee/ajakir jad/index.php/lahivordlusi/article/view/LV23.16/243 (assessed 23 October 2015)

Virtanen, Aija. 2015. The multivoicedness of written documentation: An international nursing student documenting in a second language. Published online in October 2015 in European Journal of Applied Linguistics.

Vygotsky, Lev. 1978. Mind in society: The development of higher psychological processes. Cambridge, MA: Harvard University Press.

Wood, David, Jerome Bruner \& Gail Ross. 1976. The role of tutoring in problem solving. Journal of Child Psychology and Psychiatry 17(2). 89-100. 